\title{
Pedagogical Portrait of Kyiv College Student of the Early Twentieth Century as Reflected by Behaviour Lists
}

\author{
Oleksandr Mikhno*
}

Pedagogical Museum of Ukraine, National Academy of Pedagogical Sciences of Ukraine, Kyiv, Ukraine

\author{
Who built Thebes of the seven gates? \\ In the books you will find the name of kings. \\ Did the kings haul up the lumps of rock?.. \\ And Babylon, many times demolished. \\ Who raised it up so many times? In what houses \\ Of gold-glittering Lima did the builders live? \\ Where, the evening that the Wall of China was finished \\ Did the masons go?.. \\ So many reports. \\ So many questions. \\ Bertolt Brecht
}

This article presents a generalized pedagogical portrait of Kyiv college student of the early twentieth century. The main source of research is students' behaviour lists of Pavel Galagan College that are stored in the Kyiv State Archives. It was found that behaviour lists is a form of student pedagogical characteristic in the early twentieth century. It is proved that pedagogical characteristics of that time did not have a well-defined structure and they were composed in an arbitrary manner at the end of the school year. Typically, the characteristics were very concise and comprised the following information: level of abilities, behavior, attitude towards others, hobbies, main traits of character. The main value of these characteristics is that the information given in them show a "common" student of the last century.

The author of the analysis applies microhistorical approach, manifested in the focus of research interest on "a common man" - a student - and manifested as well in experimental form of presentation of research results that has a form of a dialogue between a reader and a historian.

The article also offers a summary of application of microhistorical approach to Ukrainian research on history of education.

Keywords: microhistorical approach, history of education, student characteristic, behaviour lists.

\footnotetext{
* Email: amihno@ukr.net

${ }^{1}$ «Fragen eines lesenden Arbeiters» («Questions from A Worker Who Reads») - translated by M. Hamburger from Bertolt Brecht, Poems 1913-1956, Methuen, N.Y., London, 1976.
} 
Lucien Febvre, one of the founders of the Annales School, stated: «Every period mentally constructs its own image of the historical past, its Rome and its Athens, its Middle Ages and its Renaissance» ${ }^{2}$. In other words, every new generation of historians with new facts and new study methods perceive past events in their own way and interpret it in their own interests. Today, in the postmodernism epoch, it is advisable to talk not about only one correct interpretation, but about the multiplicity of interpretations. One of the most productive is the microhistorical approach used by historians to comprehend the global processes and phenomena through the study of the "partial". This approach is now almost never used by historians of education, so the purpose of this article is to demonstrate the possibilities of microhistorical approach in the study of such pedagogical phenomenon as a student characteristic.

\section{The Nature and Particularities of the Microhistorical Approach}

The microhistorical approach in Europe and in America was formed and developed in the 60-70s of the twentieth century. The term "microhistory" was first introduced into the scientific use by Fernand Braudel ${ }^{3}$. The founders of microhistorical approach are Italian historians such as Carlo Ginzburg, Giovanni Levy and Carlo Pony. Their works are the first example of the microhistorical method of studies ${ }^{4}$, that aim to complement, clarify or refute the established global historical constructions by choosing a human being as the study object. This change in orientation from such large structures as the history of nations and states, to small communities and "a common man" was called "anthropological turn". Due to it, emerged new types of historical science such as gender history, oral history, everyday life history, new local history and many others. The history study through the comprehension of the deep connections between people in different times and epochs, reconstruction of their world view and the correlation of a human life with the course of historical events becomes widespread in the world science at the turn of the XX-XXI centuries. The nature of mircohistorical approach was most accurately described by Jacques Revel, who argued that in order to clarify past events the most efficient is the study of the initial experience, the experience of a small group or even an individual,

\footnotetext{
${ }^{2}$ Febvre, L. The problem of unbelief in the sixteenth century: The religion of Rabelais. Harvard University Press, 1985. - P. 2

${ }^{3}$ Braudel, F. Geschichte und Soziologie / Schriften zur Geschichte. Bd.1. Gesellschaften und Strukturen. - Stuttgart, 1992. - S. 99-121. [French edition: Braudel F. Ecrits sur l'histoire, 1969. - S. 113].

${ }^{4}$ Ginzburg, C. I benandanti. Ricerche sulla stregoneria e sui culti agrari tra Cinquecento e Seicento. - Einaudi, 1966. - 57 p.; Levi, G. Das immaterielle Erbe. Eine baeuerlische Welt an der Schwelle zur Moderne. - Berlin, 1968. - 201 S. ; 22. Ginzburg C. und Poni C. Was ist Mikrogeschihcte? / Geschichtwerkstatt. - 1985. - № 6. - S. 48-52.
} 
because this experience is complex and fits into the large number of different contexts.

The choice of the scale of an object examination makes impact on results of the object study. Thus, the choice itself can serve as a strategy for knowledge. The smallest scale, according to Jacques Revel, gives no special advantages, because the most crucial is a principle of change, and not what kind of the scale is chosen. Another important feature of microhistorical approach is the presentation form of research results. And the search for the form aims at achieving not so much aesthetic as heuristic sense. It seems that a reader is invited to participate in the construction of the research object; whereas he/she is also engaged in the development of the object interpretation. ${ }^{5}$.

\section{Microhistorical Approach in the History of Education: Ukrainian Experience}

Leading Ukrainian education historian Olga Sukhomlinska distinguishes the features of microhistorical approach in the research of the history of education: "A personality and individuality are very important, but if they are taken integrally. It is not surprising when some specific topic is investigated consistently, in detail, but taken out of context, of existing realities of school of that time, methodology (in case of education), beyond existing philosophical concepts and directions (in case of development of educational ideas, especially in terms of personality), so it is impossible to imagine dimension of development of educational technologies or ideas put forward by leading teachers and their degree of novelty, because there is no broader context, text and hypertext" ${ }^{6}$. These methodological ideas are exemplified by the research of Olga Sukhomlinska called "First Ukrainian Taras Shevchenko Gymnasium. The Embodiment of Dreams of Ukrainian Intelligentsia", which highlights gymnasium activities from 1918 to 1930 based on the personality of its teacher and director Volodymyr Durdukivsky. And the author does not use epoch context to explain certain episodes from the history of the gymnasium, but vice versa, her description of gymnasium establishing and work reveals still unknown pages of educational life ${ }^{7}$. Another example of microhistorical

\footnotetext{
${ }^{5}$ Revel, J. Microanalysis and the Construction of the Social. Histories: French Constructions of the Past, New York: New Press, 1995. - P. 492-502

6 Sukhomlynska, O. Metodolohiia doslidzhennia istoryko-pedahohichnykh realii druhoi polovyny XX stolittia [Research Methodology of Historical and Pedagogical Realities of the Second Half of the Twentieth Century] / Shliakh osvity [Education Way], (4), 2007. - P. 612. (in Ukrainian).

${ }^{7}$ Sukhomlynska, O. Persha ukrainska himnaziia imeni Tarasa Shevchenka - utilennia mrii ukrainskoi intelihentsii [First Ukrainian Taras Shevchenko Gymnasium - the Embodiment of Dreams of Ukrainian Intelligentsia] / Narysy z istorii rozvytku novatorskykh navchalnovykhovnykh zakladiv v Ukraini (kinets XIX - pochatok XX stolittia) [Essays on the history
} 
approach is the work of Olga Sukhomlinska on book publication of her father, a famous Ukrainian teacher Vasyl Sukhomlynsky "I Give my Heart to the Children" $(2012)^{8}$. In the preface to this edition, entitled "In Search of the Genuine" Olga Sukhomlinska describes in detail the working process with manuscripts of the book "I Give my Heart to the Children" (they are 8 altogether); comparative check with variants, published in Soviet times; the vicissitudes of the first publication of the book (in 1968 it was published in Berlin, and only in 1969 in the Soviet Union, which at that time was an unprecedented situation).

This edition of "I Give my Heart to the Children" includes, in addition to the preface, and more applications that highlight how the manuscript was published - this process took several years - (Vasyl Sukhomlynsky's correspondence with publishers and book reviews), materials, which can cast light on the book destiny after having been published in 1968-1969, as well as bibliography reviews and reviews on it. Thus, the publication allows us to trace the complicated history of the book and thus significantly complements the image of Vasyl Sukhomlynsky as a teacher and writer, and also sheds light on the then pedagogical realities characterized aptly by Olga Sukhomlinska, "as this happened in the USSR" .

Application of microhistorical approach appeared to enhance my historical and pedagogical research devoted to the problem of student

of innovative educational and pedagogical institutions in Ukraine (late XIX - early XX century)]. - Luhansk, 2010. - S. 158-188. (in Ukrainian).

${ }^{8}$ Sukhomlynsky, V. Serce viddaju ditjam [I Give my Heart to the Children]. - Kharkiv : Akta, 2012. - 538 p. (in Ukrainian).

${ }^{9}$ Sukhomlynska, O. U poshukakh spravzhnjogho [In Search of the Genuine] / Sukhomlynsky V. Serce viddaju ditjam [I Give my Heart to the Children] - Kharkiv : Akta, 2012. - P. 5-22. on-line version: http://www.acta.com.ua/download/SerdceUkr_vstup_zmist.pdf (in Ukrainian). 
characteristics ${ }^{10}$. The main source of these studies is a student characteristic as a school paper filled in by a teacher. These characteristics appeared in the second half of the nineteenth century and exist in Ukrainian schools till present day. In different historical periods they performed various functions, but their role has remained unchanged: to summarize teacher knowledge about a student and outline the ways of further pedagogical work with him. Each such characteristic is a kind of microstory of student life at school, seen by a teacher. Characteristics analysis makes it possible to see what is normally missing from other sources: description of student appearance, information about his parents, comments about rules violation of the institution and more. But the most important is that the information contained in characteristics not only significantly expands the idea of school life in different historical periods, but depicts a student as it is.

The main source of research in this article is behaviour lists, a form of student characteristic, that were common in schools in the early twentieth century. Among the archival documents that I reviewed the best quality and quantity of behaviour lists were preserved in Pavlo Galagan College.

This private school for boys existed in Kiev from 1871 to 1920. It was founded by famous Ukrainian landowner and philanthropist Grygory Galaganov in honor of his only son Pavlo, who died at the age of 16 . The college was one of the best educational establishments of that time, aiming at preparing students to enter the Kyiv University of Saint Volodymyr. Teaching in the college was carried out by programs and plans of the Ministry of National Education for schools. But Grygory Galagan believed that special attention should be paid to the artistic side of education, so subjects such as manual labor, singing and drawing were also taught in the college. For the purpose of students physical development the school courtyard was equipped for gymnastics, croquet and lawn-tennis, and in winter for ice rink. Before going to sleep, students could

${ }^{10}$ Mihno, O. Vasyl Sukhomlynsky on Psychological and Educational Characteristics of Student's Personality / Edukacja - Technika - Informatyka, Rzeszów, 2013, s. 507-511. Online version: http://cejsh.icm.edu.pl/cejsh/element/bwmeta1.element.desklight-1b8268ee66a6-4138-8f8d-1953247ae886 ; Mikhno, O. Psykhologhichna majsternistj A. S. Makarenka jak avtora psykhologho-pedaghoghichnykh kharakterystyk osobystosti [Psychological skills of Anton Makarenko as the Author of Psychological and Pedagogical Characteristics of Personality] / Pedaghoghichni nauky : teorija, istorija, innovacijni tekhnologhiji [Pedagogical Sciences: Theory, History, Innovative Technologies]. - Sumy, 2013. - № 3 (29). - P. 268-277 (in Ukrainian); Mikhno, O. Pedaghoghichni statti Ljva Tolstogho jak dzherelo doslidzhennja problemy psykhologho-pedaghoghichnoji kharakterystyky uchnja [Leo Tolstoy’s Pedagogical Articles as a Source of the Study on Psychological and Educational Student's Characteristics] / Pedaghoghichnyj dyskurs [Pedagogical discourse]. - Khmelnytsky, 2013. - P. 481-486. Online version: http://peddyskurs.kgpa.km.ua/en/archive-of-issues/issue-15-2013/474 (in Ukrainian). 
walk outside in the courtyard in the light of the electric lamp ${ }^{11}$. That is, in the college were created all conditions for training and education of boys.

Students' behaviour lists of Pavlo Galagan College are kept at the State Archives of. Kyiv ${ }^{12}$. I reviewed totally around 200 behaviour lists dated from 1907 to 1911. Each behaviour list is a separate "case" in archival storage. For further convenience we will refer to these sources, noting in parentheses "case" number.

The results of the research will be presented in this article in an unusual form of reader and historian dialogue, which is a kind of experiment.

\section{Behaviour List as a Model of Student Characteristic in Early Twentieth Century}

Reader: What was a behaviour list and where this name comes from?

Historian: The name comes from the French word «conduite» - behavior. A behaviour list had a few sheets of A4 paper that were published in typographic way. On the front page were cited student family and first name, the period of his stay in school: when he entered the college and when finished it; on the back page were repeated student's family and first name, indicated whether he learns at his own expense, or he is a scholarship student, his year of birth, father's social status, religion, year and condition entry (by exam or by education certificate), previous place of learning, behavior evaluation. Next page of the behaviour list had a table with columns as follows: "The month and the date", "Faults and everything remarkable concerning a student", "Punishments and other measures", "Absenteeism: illness / serious reason / for no reason", "Behaviour evaluation". These graphs were filled in by a classroom teacher during the school year. After these entries a teacher wrote student's characteristic in the column "Faults and everything remarkable concerning a student".

Reader: That is to say that a behaviour list is a kind of student personal file, which contains basic information about him?

Historian: Yes it is. The behaviour list structurally consisted of three parts: biographical information, records of college code abuse and punishments for these violations and student's characteristic.

Reader: Can you give an example of biographical information of a specific student at school?

\footnotetext{
${ }^{11}$ Ezhegodnik Kollegii Pavla Galagana s 1 oktjabrja 1907 po 1 oktjabrja 1908 [Annual of the Pavel Galagan College from the $1^{\text {st }}$ October of 1907 to the $1^{\text {st }}$ October of 1908]. $13^{\text {th }}$ year. Kyiv, 1908. - P. 15-16. (in Russian).

${ }^{12}$ Derzhavnyj arkhiv m. Kyjeva. Fond 185 «Kyjivsjka koleghija Pavla Ghalaghana». 1408 sprav [Kyiv State archives. Collection 185 "Pavlo Galagan College". 1,408 cases].
} 
Historian: Of course. It's easier to do, because this information is present in absolutely all behaviour lists, but comments on behavior and characteristics in many lists are missing. Here, for example, in George Zenkevich's behaviour list was stated that he was born on the $16^{\text {th }}$ of November in 1894 , he is the son of professor assistant, he studied at the Kyiv First Gymnasium, entered the college on the $12^{\text {th }}$ August in 1909 by the results of the exam with grade "5" of behavior (712). Unfortunately, there were no more entries in this behaviour list. And this case is not unique.

Reader: But even in this biographical information you can find out some interesting points. Say, what was the origin of college students or was the institution accessible for the representatives of various social strata?

Historian: Judge by the entries, there were no restrictions on student's social status in college. Thus, according to behaviour lists in the institution studied: peasant's son (810), nobleman's son (763), clerk's son (761), priest's son (752), Duke's son (677), Cossack's son (683), merchant's son (657), privatdocent's son (712), bourgeois' son (814), honorary citizen's son (771), state councilor's son (704). Apparently, boys are representatives of almost all social strata, from a peasant to a prince.

Reader: As for religion there were some restrictions?

Historian: Yes, and it is clearly spelled out in school statute, which says that "young people of all classes, but only the Orthodox or Greek Catholic can study here" ${ }^{13}$.

Reader: You have said that among the biographical data there was information about the previous place of study. What are these institutions?

Historian: The geography of these schools is quite wide, but what draws our attention that the schools are mostly Ukrainians: of Bila Tserkva (689), of Zhytomyr (674), of Zhmerinka (777), of Zlatopil'a (797), Kyiv First Gymnasium (752), Kyiv Second Gymnasium (771), Kyiv-Pechersk (677), Kiev Gymnasium of Vyacheslav Petro, Kiev private school of Andronyk Strepovych (806), of Nemyriv (731), of Poltava (757), of Pryluky (748), of Radom (761), of Cherkasy (810), of Chernigiv (690), and Kiev Real School of St. Catherine (683), Hlukhiv Seminary (788). Among behaviour lists that I looked through only a few students came to the college after having studied in schools that were situated not in the Ukrainian lands: Second Gymnasium of Orlov (657), Emperor Alexander III Gymnasium of Viazma (756), Third Gymnasium of St. Petersburg (799).

Reader: What reprimands are most often noted in behaviour list?

\footnotetext{
${ }^{13}$ Ezhegodnik Kollegii Pavla Galagana s 1 oktjabrja 1907 po 1 oktjabrja 1908 [Annual of the Pavel Galagan College from the $1^{\text {st }}$ October of 1907 to the $1^{\text {st }}$ October of 1908]. $13^{\text {th }}$ year. Kyiv., 1908. - P. 135. (in Russian).
} 
Historian: Mostly these records are related to conduct violation. For example: "late for morning prayer" (810, 677, 732, 690, 674), "has repeatedly been seen late for morning prayer, moreover, was often in bed until nine o'clock, sometimes went to bed after prayer" (814), "came from the theater at 3 a.m." (810, 732, 690, 674, 814), "left the theater and nobody knew where he was while he said that went home" (677), "without permission was walking on the street at 7.30 p.m. (a weekday)" (732), "was back from the merchant garden at 12.15 p.m." (814),"at the lessons of mathematics was reading menacing books" (732),"cast paper arrow during the class" (788), "behaved badly at Latin class" (788). As you can see, the students of the early twentieth century were very similar to modern students, though punishments for abovementioned faults were quite serious.

Reader: I wonder what punishment was, for example, for being late for a prayer or bad behavior during the lesson?

Historian: Typically, for being late for the prayer teacher made a remark that was added to the behaviour list, and only then reprimand. If the delay was regular, a student could have no vacations (810). Much more severe was the punishment in the form of lower grades in conduct. It was applied for fairly serious faults and was substantiated in detail. For example, in Boris Navrotsky's behaviour list we read: "During the second quarter of the 1910-1911 the mark "4" was given for being rude and getting into an argument with the Director. In the third quarter of the school year the mark " 4 " was put for being late from Christmas vacations without good reason ... While transferring to fourth class the college board decided to warn Navrotsky's parents that if their son receives first mark " 4 " of behavior in the fourth class, he will be deprived of scholarships" (748). Or this: "In the last semester received a mark "4" for behavior because he smoked at the station and didn't fulfill the order to throw immediately the cigarette" (731).

Reader: We discussed the standard reprimands and punishments. How do characteristics look like?

Historian: First of all, I must admit that characteristics are present not in all behaviour lists. Typically, they look like small posts made by a classroom teacher at the end of the school year. Sometimes these records were entitled by a word "characteristic". The characteristic volume was brief: a few sentences about student's character, behavior, abilities.

Reader: Could we call characteristic a few sentences about a student?

Historian: Here is an example of laconic but eloquent characteristic: "Rather a child than a young man. He is very nice and genuine human being. He studies brilliantly, behaves impeccably. Excellent scholar" (730). This is a brief description of Liubchenko Leonid, who studied at the college from 1910 to 1915. Or this is another record: "Oryehov is a passive, wordless, gloomy, and not friendly person, but quite good-natured. He behaves quite correctly. His abilities are weak, but he does his best in studies" (756). As we see, a classroom 
teacher characterizes briefly, but deeply his students, he sees their true self. In contrast to these concise characteristics, there are those in which a student is not visible. For example: "Ovsievsky is an educated young man with quite correct behavior. During the school year he was not noticed in nothing shameful. He has abilities, and studies diligently" (757). We must agree that it is difficult to see a unique student behind this general information.

Reader: In fact, all the characteristics are short, but differ in quality. If first two characteristics describe young man who we can easily imagine, the last one is quite dim, faceless and may be applied to half of the students. And do behaviour lists contain more detailed characteristics with some examples from the life of students?

Historian: Of course, they do. For example, sometimes in the characteristic student's vocation to a school subject is noted, "he has a special interest in physics" (677). Or pupil's passion is described: "All his spare time he practiced playing the violin, first under the direction of music teacher at the college, and the last two years, he visited Kyiv Music College and thus achieved in particular the violin virtuosity" (671). It is interesting to read about students' faults that were added to the characteristics: "The only Zankevych's fault, which was considered by the college panel, is that he allowed himself to visit the person without school permission, and drank wine there" (711). There is another entry: "During the year he was seen repeatedly in violation of school life rules and practices; he quarreled with his comrades, shattered the calm in the dormitory, beat bulbs and window glass, and went crazy in the yard. In general, his character is annoying, troublesome, but not evil" (799).

Reader: What information about school activities was added to the characteristics?

Historian: First of all, it's the level of abilities, and it is important that the level of abilities is specified in the students' studies: "good abilities: he studies well"(810), "average abilities, but a well-educated and mentally healthy young man" (763), "he studied well in all subjects owing to not only very good abilities, but also to unusual diligence and strength of will" (761), "very capable, studious young man" (752), "he has good abilities and mental development" (732 ) "modest abilities" (689), "he has sufficient abilities, but because of laziness he studied not always hard" (806), "the young man is capable, he could do a course more successfully, but excessive nervousness and impulsiveness detain his success in studies" (814), "he has average abilities - a circumstance for him as a scholar, is not very advantageous" (762).

Reader: It's obvious that to make such conclusions a classroom teacher had to know well his students. Was the work on writing students' characteristics somehow regulated, there were any rules for its writing?

Historian: The charter of the college stated that a teacher "must be as close as possible to his students, know all their essential needs, study their 
characters" $^{14}$. It refers to the activity that precedes characteristic writing. Given brevity of numerous characteristics or their lack in behaviour lists help us conclude that characteristic writing was not obligatory for a classroom teacher and it depended on how well he knew his students, as well as how well he could generalize the results of his observations.

Reader: Do students' characteristics contain synthesis and analysis, or it's a simple list some facts?

Historian: If a characteristic is included into the behaviour list, it contains synthesis, analysis, and sometimes recommendations. This characteristic is exemplified by the following entry: "Gasiuk studies very well but painfully developed selfishness, acridity and cruel temper established hostile relations between him and classmates. His college duties he performs exactly. He looks like a very well-groomed young man. He seems to become a serious worker. But a bad impression is made by his non-peaceful nature and inability to be on good terms with other students without teacher's intervention. He is an incredulous, reserved person. Gasiuk first should develop sociability skills "(688). It describes student's particular nature and its impact on studies and relationship with others, including pedagogical recommendations aimed at improving student's character.

Reader: How are described students' characters in characteristics? Are employed there familiar to us terms as sanguine, choleric, and so on?

Historian: Sanguine, choleric, melancholic and phlegmatic are different types of temperament. Those words are never used in the characteristics. As for the description of the character, these records are made on the basis of external manifestations of student's behavior, for instance: "he is quiet and reserved" (810), "he has quiet nature, polite with teachers and friendly with other students" (806), " his apparent rudeness and selfishness begin to appear, for example, in impoliteness and stubbornness and permanent deviations from college rules" (732). Teacher's general impressions of students are somewhat more described: "he is notable for modesty, diligence and calm temper" (674), "hard-working, serious" (731), "quiet, meek, humble, diligent, conscientious, faithful" (762) "good-mannered, gentle, peaceable "(711),"fearful "(776) and others. There was no deeper description of students' characters there, which is not surprising seeing that characterology as a science appeared only in the early twentieth century, was not spread so much at that times. Educators didn't use its advances in characteristics writing. Although, given quality, quantity and variety of students' characteristics suggest that classroom teachers were familiar with

\footnotetext{
${ }^{14}$ Ezhegodnik Kollegii Pavla Galagana s 1 oktjabrja 1907 po 1 oktjabrja 1908 [Annual of the Pavel Galagan College from the $1^{\text {st }}$ October of 1907 to the $1^{\text {st }}$ October of 1908]. $13^{\text {th }}$ year. Kyiv., 1908. - P. 9. (in Russian).
} 
research of Olexander Virenius ${ }^{15}$, Constantine Yelnytsky $^{16}$, and especially Olexander Lazursky ${ }^{17}$ that could be applied in monitoring of students and writing their characteristics.

Reader: As far as I understand that characteristics were written in an arbitrary manner without any plan.

Historian: Absolutely right. Although if you analyze all these records together, it can be argued that they comprise some basic information about students, namely the level of abilities, behavior, attitude towards others, hobbies, main traits of character. At large, behaviour lists containing at least a brief pupil's description, show a "common" student, and that is their greatest value.

Reader: I will try following what I have heard to draw a student's portrait of Kiev college of the early last century. Portrait palette depends on the variety of information about a student, and value of colors is reliant on the amount and specificity of its information. Consequently, a graduate of the Pavlo Galagan College of the early twentieth century is a young man aged from 15 to 18 years old, who studies in school. In college he learns at his own expense or has a scholarship, and abilities to learn. If it is not from Kiev, then he lives in dormitory at the college. In addition to classes, he attends theater, does sports. His behavior can't be called perfect: as a young man who spends a lot time among the peers, he is prone to boy's antics. The pages of behaviour lists create such an image of college student.

Historian: You have painted a vivid and lively portrait. Only one clarification: this pedagogical portrait doesn't possess appearance description, because behaviour lists virtually contain no information on the physical condition, such as height, weight, and other physical data. Why is it pedagogical? Because we see a student in school with teacher's eyes. graduates?

Reader: And do you know something about the future of college

Historian: We're talking about behaviour lists. Such information wasn't added to it. But as I mentioned, the college published annual books, and they have this information displayed, for example: "Levytsky Grygory Andriiovich, born in Kiev province in 1878. He graduated from the College in 1897, the $23^{\text {rd }}$

\footnotetext{
${ }^{15}$ Virenius, A. S. Harakteristika uchashhegosja. Teloslozhenie, temperament i harakter v poru shkol'nogo vozrasta [Student's Characteristics. Constitution, temperament and character at school age]. - St. Petersburg, 1904. - 123 p. (in Russian).

${ }^{16}$ El'nickij, K. V. Harakteristiki devochek [Characteristics of girls]. - Moscow, 1895. - 173 p. (in Russian).

${ }^{17}$ Lazurskij, A.F. Shkol'nye harakteristiki [School characteristics]. - St. Petersburg, 1908. 228 p. (in Russian).
} 
class of graduates. He graduated from Kyiv University of St. Vladimir. Now he works in the laboratory at the Kiev Polytechnic Institute" ${ }^{18}$.

Reader: Can you describe your feelings when you were working with behaviour lists?

Historian: Very good question. First of all, I would say that a historian can't help researching documents, epoch, and country. When some unique testimonies fall into historian's hands, he feels excitement, kind of research illumination. Behaviour lists of students of the early twentieth century made me feel "authenticity" of documents. Judging from the records in archives (each case has a sheet in the archive, where is indicated who and when looked it over), I was the first person for 100 years, who worked with these documents. Discovery joy is hard to compare with anything. This is a real intellectual enjoyment. And I have found pleasure not only in the outcome but also in the process of creative research.

\section{Conclusion}

The results of the study of behaviour lists are an attempt to apply microhistorical approach to the history of education. Still the research in the history of education was focused on "structure" and "community." If a person was considered in education, he/she usually was the identity of large scale: the teacher who made a significant contribution to the development of education. I wanted to show a "common" man (a student, a teacher) of these "structures" and "communities". It must be emphasized that the use of microhistorical approach in the history of education is the correlation of microhistorical analysis with previous experience in macro-analysis, not vice versa. That is, trying to understand the phenomenon of student pedagogical characteristic in a specific historical period (the early twentieth century), I turned to behaviour lists, documents containing specific teaching experience in its unique single expression. This made it possible to determine not only main features of student's characteristic as a document at the beginning of the last century, but, above all, to see how a student looked like one hundred years ago. Of course, a student studied and lived in a certain educational "structure" (Kyiv Pavlo Galagan College as secondary school) and was in particular "community" (student contingent), but the "face" of the institution is, above all, his disciples, that is why is my research interest was focused mainly on a student.

Another manifestation of microhistorical approach is an unusual form of presentation of research results -a dialogue between a reader and a historian.

\footnotetext{
${ }^{18}$ Ezhegodnik Kollegii Pavla Galagana s 1 oktjabrja 1907 po 1 oktjabrja 1908 [Annual of the Pavel Galagan College from the $1^{\text {st }}$ October of 1907 to the $1^{\text {st }}$ October of 1908]. $13^{\text {th }}$ year. Kyiv., 1908. - P. 22. (in Russian).
} 
This form gives the maximum opportunity to engage the reader into the process of documents research and makes him a co-creator of historical reconstruction. During the dialogue the reader can verify his impressions, ideas, clarify something, and sometimes understand complicated points. Or, like in this article, to become a coauthor of pedagogical portrait of Kyiv college student of the early twentieth century. Finally, I note that my thoughts on the application of microhistorical approach to research in the history of education are purely subjective. However, we must remember that the creation of a new area of research is always intuitive and not clearly delineated, the methodology could appear later. 